(c) American Dairy Science Association, 2006.

\title{
Effect of Scraping Frequency in a Freestall Barn on Volatile Nitrogen Loss from Dairy Manure ${ }^{1}$
}

\author{
V. R. Moreira ${ }^{\star 2,3}$ and L. D. Satter ${ }^{\star} \dagger$ \\ *Department of Dairy Science, University of Wisconsin, Madison 53706 \\ †U.S. Dairy Forage Research Center, USDA Agricultural Research Service, Madison, WI 53706
}

\begin{abstract}
The objective of this investigation was to evaluate the effect of scraping frequency ( $2 \times$ vs. $6 \times$ daily) on $\mathrm{N}$ volatilization from manure on the floor of a dairy freestall barn. Three trials (crossover design) were conducted in the summers of 2001 and 2002, and in the winter of 2003. Nitrogen volatilization was estimated from the change in the $\mathrm{N}: \mathrm{P}$ ratio in excreta at the time of excretion to the time when manure was scraped from the barn. Total $\mathrm{N}$ loss was considered a maximum estimate of $\mathrm{NH}_{3}-\mathrm{N}$ loss, because small amounts of nonammonia $\mathrm{N}$ may be volatilized. Nitrogen was determined after manure subsamples were lyophilized; P content was measured by direct current emission spectroscopy of ashed subsamples of manure. Lactating dairy cows were fed high-protein (18.5 to $19.3 \%$ crude protein), alfalfa-based diets. Average milk yield was 31.9 (SD = 7.4) $\mathrm{kg} / \mathrm{d}$. Scraping frequency had no effect on $\mathrm{N}$ loss in summer 2001. An average of $41 \%$ of excreted $\mathrm{N}$, or $238 \pm 19.0 \mathrm{~g}$ of N/d per cow, was volatilized. For the trial in summer 2002, nitrogen volatilization was reduced from $50 \%$ of the excreted $\mathrm{N}$ with $2 \times$ to $46.7 \%$ with $6 \times$, equivalent to 265 and $248 \mathrm{~g}$ of $\mathrm{N}$ lost/d per cow, respectively. Scraping had no effect on $\mathrm{N}$ volatilization during the winter trial. An average of $17.7 \%$ of excreted $\mathrm{N}$ was volatilized during the winter, equivalent to 109 $\pm 11.0 \mathrm{~g}$ of $\mathrm{N}$ lost/d per cow. Scraping frequency of manure had little or no effect on $\mathrm{N}$ loss from manure in a freestall barn. Nitrogen loss during the winter was less than half of the loss during the summer.

Key words: nitrogen to phosphorus ratio, nitrogen volatilization, dairy, season

\footnotetext{
Received November 28, 2005.

Accepted February 1, 2006.

${ }^{1}$ Trade names and the names of commercial companies are used

${ }^{2}$ Corresponding author: VMoreira@agcenter.lsu.edu

${ }^{3}$ Current address: Louisiana State University Agricultural Center
} in this report to provide specific information. Mention of a trade name or manufacturer does not constitute a guarantee or warranty of the product by the USDA or an endorsement over products not mentioned. Southeast Research Station, Highway 16 West, P.O. Drawer 567, Franklinton, LA, 70438.
\end{abstract}

\section{INTRODUCTION}

There is growing concern about the amount of $\mathrm{NH}_{3}$ released into the atmosphere. Ammonia can react in the atmosphere with sulfur and nitrogen oxides produced by power plants and vehicles, resulting in formation of small particles $(<2.5 \mu \mathrm{m})$ that can reduce visibility and increase the risk of cardiovascular and respiratory diseases (Wolfe and Patz, 2002; Kaiser, 2005). Elevated levels of atmospheric $\mathrm{NH}_{3}$ can result in soil acidification and damage to forests. Deposition of $\mathrm{NH}_{3}$ and $\mathrm{NH}_{4}{ }^{+}$can lead to overfertilization of water bodies and fragile lands, altering plant populations, and reducing biodiversity (Carpenter et al., 1998; Tilman, 1999; Rabalais, 2002). Consequently, $\mathrm{NH}_{3}$ volatilization was defined as a major concern by an NRC ad hoc committee (Air Emissions from Animal Feeding Operations; NRC, 2003).

The largest anthropogenic source of atmospheric $\mathrm{NH}_{3}$ is thought to originate from the breakdown of organic compounds in animal manure. National inventories suggest that livestock and poultry operations contribute 50 to $80 \%$ of all $\mathrm{NH}_{3}$ released to the atmosphere in Western Europe and North America (ECETOC, 1994; EPA, 2004). Consequently, livestock and poultry producers are under increasing pressure to reduce emissions. Unfortunately, there is limited information available on the impact that different management practices can have on $\mathrm{NH}_{3}$ emissions, and most of the literature that is available suggests large variation among estimates and among management practices (NRC, 2003).

Nitrogen loss from manure begins at the time of excretion of urine and feces. Most urinary $\mathrm{N}$ is present as urea, which can be quickly hydrolyzed to $\mathrm{NH}_{3}$ by microbial ureases present in feces (Muck, 1982). The amount of urea in urine is highly correlated to protein intake; thus, diets with greater protein content are associated with greater $\mathrm{NH}_{3}$ loss from manure (Smits et al., 1995; Kröber et al., 2000). Ammonia volatilization from manure can be reduced by minimizing protein intake through ration balancing (Frank and Swensson, 2002). Appropriate management of manure, however, will be necessary for further reduction in $\mathrm{NH}_{3}$ loss. A significant proportion of total $\mathrm{NH}_{3}$ loss from a dairy 
operation occurs from within the barn (Bussink and Oenema, 1998; Monteny and Erisman, 1998). One practice that could conceivably reduce $\mathrm{NH}_{3}$ volatilization from the dairy freestall barn is to remove manure quickly from the barn floor by more frequent scraping.

The objectives of this study were to determine if frequent manure scraping ( 6 times vs. twice daily) of a dairy freestall barn was effective in reducing nitrogen loss within the barn, and if season (summer vs. winter) would influence the effectiveness of scraping frequency.

\section{MATERIALS AND METHODS}

\section{Experimental Design}

Three trials were conducted at the USDA-ARS US Dairy Forage Research Center Experimental Farm located in Prairie du Sac, Wisconsin. Two trials were carried out during the summer in 2001 and 2002. A third study took place in the winter of 2003 . Treatments consisted of scraping manure either twice $(\mathbf{2} \times, 0700$ and $1700 \mathrm{~h})$ or 6 times $(\mathbf{6} \times, 0900,1200,1500,2000,0100$, and $0600 \mathrm{~h}$ ) daily during each of two 24 -h periods. Scraping times in treatment $2 \times$ were chosen according to milking events, because pens were empty of cows at those times. Cows were divided into 4 separate pens. Each pen was considered an experimental unit in a crossover design. Cows had free access to back (stalls) and front (feed bunk) alleys in each pen $\left(79.5 \mathrm{~m}^{2}\right.$ of alley/pen, Figures 1 and 2). Alley animal densities were similar (3.31 to $3.61 \mathrm{~m}^{2} / \mathrm{cow}$ ) for all 4 pens throughout the trials. Stalls were fit with mattresses and covered with straw. Approximately $1.5 \mathrm{~kg}$ of wheat straw per cow was chopped daily on the mattresses of each pen for cow comfort. Stalls were groomed daily.

\section{Cow Management}

Summer 2001. Midlactation cows ( $\mathrm{n}=144 ; 69$ primiparous and 75 multiparous) were randomly distributed among 4 pens for an ongoing $\mathrm{P}$ feeding trial. Pens F5 and F7 actually included 2 pens each, and thus contained twice as many cows as pens F1 and F2 (Figure 1). Diets were fed ad libitum once daily and contained 2 levels of $\mathrm{P}(0.38$ and $0.55 \%$ of $\mathrm{DM})$ and similar $\mathrm{CP}$ (Table 1). Each treatment (scraping frequency) was applied to pens containing both dietary $\mathrm{P}$ levels. Cows were milked twice daily and averaged $31.6(\mathrm{SD}=6.7)$ $\mathrm{kg}$ of milk/d and $168 \pm 89$ DIM.

Summer 2002. Midlactation cows ( $\mathrm{n}=96 ; 41$ primiparous and 55 multiparous) producing $28.6 \pm 6.1 \mathrm{~kg}$ of $\mathrm{milk} / \mathrm{d}$ at $234 \pm 81 \mathrm{DIM}$ were randomly distributed among the 4 pens (Figure 2). Herd diet was fed once daily ad libitum for at least $15 \mathrm{~d}$ before and throughout the experimental period (Table 1).

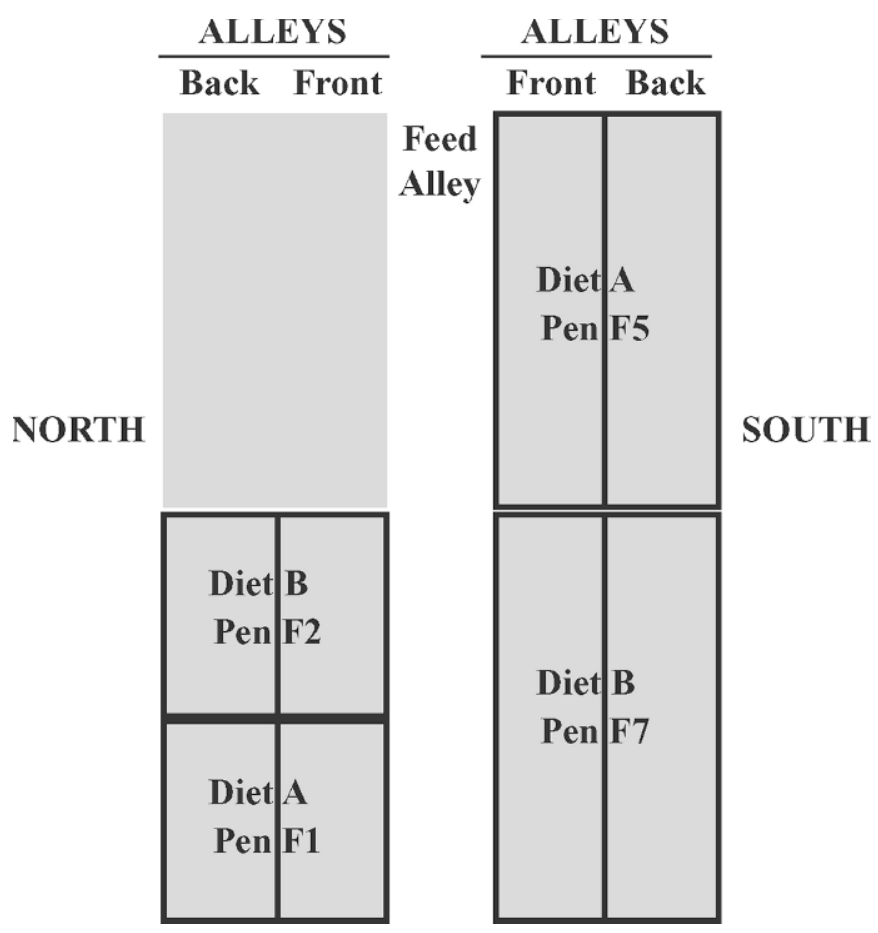

Figure 1. Schematic of the freestall pens used during the summer 2001 trial. Diets A and B indicate different $P$ content offered during the experimental period for a concurrent study. Each scraping frequency treatment ( $2 \times$ vs. $6 \times$ daily) was applied to pens in the north or south sides of the barn in a crossover design. Front alleys faced the feed bunk, and back alleys had 2 rows of stalls.

Winter 2003. Lactating cows ( $\mathrm{n}=92 ; 32$ primiparous and 60 multiparous) averaging $36.6 \pm 8.9 \mathrm{~kg}$ of milk/d and $73 \pm 90$ DIM were randomly distributed among the 4 pens (Figure 2). Herd diet was fed once daily ad libitum for at least $15 \mathrm{~d}$ before and throughout the experimental period (Table 1).

\section{Scraping, Sampling, and Analyses}

Manure was scraped, piled, and mixed thoroughly on the alley using hand scrapers $(61.0 \times 17.8 \mathrm{~cm})$ and a scoop shovel $(37.5 \times 47.6 \mathrm{~cm})$ before sampling. Approximately $50 \mathrm{~cm}$ on each side of the gates separating pens was not scraped to avoid contamination between pens. Manure was scraped and sampled separately for each alley in summer 2001 (Figure 1). Manure from both alleys was mixed, and samples were collected for each pen in summer 2002 and winter 2003 (Figure 2). Temperature was measured in 3 to 5 points of the manure pile and averaged. Two samples were randomly collected in two 18.9-L buckets from the piles with a scoop shovel after every scraping from each pen. Alleys were cleaned with automatic scrapers before the onset of each experimental period and after each sampling pe- 


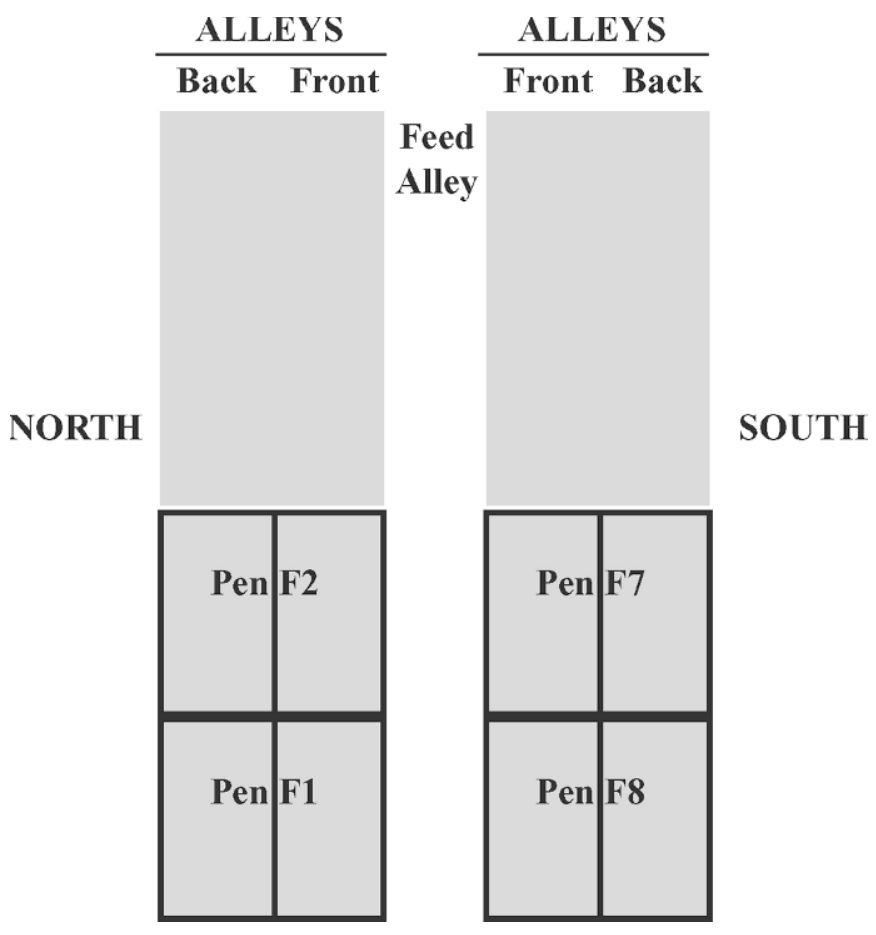

Figure 2. Schematic of the freestall pens used during the summer 2002 and winter 2003 trials. Each scraping frequency treatment $(2 \times$ vs. $6 \times$ daily) was applied to pens in the north or south sides of the barn in a crossover design. Front alleys faced the feed bunk, while back alleys had 2 rows of stalls. riod. Start-up cleaning occurred at 1500 and $1700 \mathrm{~h}$ before $d 1$ and at 2000 and 1700 before $d 2$ for treatments $6 \times$ and $2 \times$, respectively.

Samples were brought to the laboratory, hand-mixed, and 3 subsamples were drawn by inserting a $680-\mathrm{mL}$ plastic jar upside-down at approximately the top, middle, and bottom of the 18.9-L bucket. The 3 subsamples were placed in a 7.6-L pail and mixed again. Two 90$\mathrm{mL}$ aliquots were taken from each bucket for $\mathrm{N}$ analyses and $\mathrm{pH}$ was recorded. Samples were immediately acidified with $2 \mathrm{~mL}$ of $12 \mathrm{M}$ sulfuric acid to lower $\mathrm{pH}$ to 2 or below, and subsequently stored in a freezer to minimize N loss. Samples for N analyses were lyophilized in a VirTis Freeze Dryer (SP Industries Co., Gardiner, NY). Two additional aliquots of approximately $350 \mathrm{~g}$ each were collected for $\mathrm{DM}\left(60^{\circ} \mathrm{C}\right.$ forced-draft oven $)$ and $\mathrm{P}$ analyses. Feed samples were collected on the last day of each experiment and were dried in a $60^{\circ} \mathrm{C}$ forceddraft oven for at least $48 \mathrm{~h}$. Overall, hand-scraping, sampling, running of the automatic scrapers, and sample preparation in the laboratory (including subsampling, acidification, and storage in the freezer) lasted for approximately 1 to $1.5 \mathrm{~h}$ for both pens during each sampling period.

All dried samples were ground with a Wiley mill (Arthur H. Thomas, Philadelphia, PA) to pass through a 1mm screen. A Leco FP-2000 Nitrogen/Protein Analyzer (Leco Co., St. Joseph, MI) was used to determine total N by the combustion method (AOAC, 1990). Phosphorus content was measured as described by Combs and Satter (1992).

Table 1. Ingredient composition of experimental diets fed during summer (2001 and 2002) and winter (2003) trials evaluating the effect of manure scraping frequency on $\mathrm{N}$ volatilization from a freestall barn

\begin{tabular}{|c|c|c|c|c|}
\hline \multirow[b]{2}{*}{ Ingredient, $\%$ of $\mathrm{DM}$} & \multicolumn{2}{|c|}{ Summer 2001} & \multirow{2}{*}{$\begin{array}{l}\text { Summer } \\
2002\end{array}$} & \multirow{2}{*}{$\begin{array}{l}\text { Winter } \\
2003\end{array}$} \\
\hline & $\operatorname{Diet} \mathrm{A}^{1}$ & Diet $B^{2}$ & & \\
\hline Alfalfa silage & 26.0 & 26.0 & 32.4 & 23.9 \\
\hline Corn silage & 26.0 & 26.0 & 25.4 & 20.1 \\
\hline Whole cottonseed & 4.00 & 4.00 & 3.76 & - \\
\hline High-moisture shelled corn & 23.0 & 22.3 & 20.9 & 28.9 \\
\hline Roasted soybean & 14.5 & 14.5 & 11.7 & 15.2 \\
\hline Soybean meal & 5.20 & 5.30 & 2.71 & 1.76 \\
\hline Blood meal & - & - & 0.72 & 0.85 \\
\hline Corn distillers & - & - & - & 6.22 \\
\hline Limestone & 0.40 & 0.40 & 0.63 & 1.08 \\
\hline Monosodium phosphate & - & 0.60 & - & - \\
\hline Dicalcium phosphate & - & - & 0.25 & 0.29 \\
\hline Salt & 0.30 & 0.30 & 0.43 & 0.52 \\
\hline Sodium bicarbonate & 0.40 & 0.40 & 0.60 & 0.62 \\
\hline Yeast & - & - & 0.28 & 0.30 \\
\hline Vitamin-mineral supplement ${ }^{3}$ & 0.10 & 0.10 & 0.12 & 0.13 \\
\hline Magnesium oxide & 0.10 & 0.10 & 0.10 & 0.13 \\
\hline
\end{tabular}

\footnotetext{
${ }^{1}$ Diet A contained phosphorus to meet requirement $(0.38 \% \mathrm{P})$.

${ }^{2}$ Diet $\mathrm{B}$ contained phosphorus to exceed requirement $(0.55 \% \mathrm{P})$.

${ }^{3}$ Vitamin-mineral supplement (per kilogram of product): $194 \mathrm{~g} \mathrm{Ca}, 55.1 \mathrm{~g} \mathrm{~S}, 6.2 \mathrm{~g} \mathrm{Zn}, 5.1 \mathrm{~g} \mathrm{Mn}, 2.4 \mathrm{~g} \mathrm{Fe}$, $1.3 \mathrm{~g} \mathrm{Cu}, 43.1 \mathrm{mg} \mathrm{Co}, 320 \mathrm{mg} \mathrm{Se}, 7,100 \mathrm{k} / \mathrm{U}$ vitamin A, 2,200 k/U vitamin D, and 1,800 k/U vitamin E.
} 


\section{Description of the N:P Methodology}

Volatile N loss was estimated based on the difference between estimated nitrogen:phosphorus ratio $(\mathrm{N}: \mathrm{P})$ of fresh excreta and measured N:P in scraped manure. Excretion of $\mathrm{N}$ and $\mathrm{P}$ was estimated as amount of ingested nutrients minus the amount of nutrients secreted in milk, according to Van Horn et al. (1994). Dietary DMI was estimated using the NRC (2001) model set for each cow, using 4\% FCM, average BW $(636 \mathrm{~kg})$, and week of lactation as inputs. Feed CP and $\mathrm{P}$ content were adjusted in the NRC (2001) model according to actual analysis of each feed. Milk fat and CP content used for calculations of intake and excretion in the 3 trials were $3.50 \pm 0.44 \%$ and $3.20 \pm 0.20 \%$, respectively, and were based on average DHIA records of the cows used. Milk $\mathrm{P}$ was fixed at $0.09 \%$ according to NRC (2001). Milk nutrient yields were calculated and subtracted from daily intakes to give excreted nutrient loads. The estimated amount of $\mathbf{N}$ excreted $\left(\mathbf{N}_{\text {exc }}\right)$ was divided by the estimated excreted $\mathrm{P}$ to determine the $\mathrm{N}: \mathrm{P}$ as excreted by the animal (N:P $\mathbf{\text { exc }}$ ). Scraped manure was analyzed for $\mathrm{N}$ and $\mathrm{P}$ and ratios were calculated for each sample ( $\left.\mathbf{N}: \mathbf{P}_{\text {man }}\right)$. Nitrogen loss as percentage of $\mathrm{N}_{\text {exc }}$ was estimated as 1 minus the quotient of $\mathrm{N}: \mathrm{P}_{\text {man }}$ and $\mathrm{N}: \mathrm{P}_{\text {exc }}:\left[1-\left(\mathrm{N}: \mathrm{P}_{\operatorname{man}} / \mathrm{N}: \mathrm{P}_{\text {exc }}\right)\right] \times 100$. The fractional $\mathrm{N}$ loss was multiplied by $\mathrm{N}_{\text {exc }}$ to obtain an estimate of the amount of $\mathrm{N}$ lost.

\section{Statistical Analyses}

Statistical analyses were performed using the MIXED procedure of SAS 8.0 (SAS Institute, 1999) for a crossover design. Scraping times were adjusted on $2 \times$ to match $6 \times$ at $0600 \mathrm{~h}$, and on $2 \times$ and $6 \times$ to match at $1600 \mathrm{~h}$ before running the model. The model set to test the effect of different scraping frequencies on manure $\mathrm{N}$ volatilization included treatment, day, and treatment $\times$ day interaction. Alley and its interactions with day and day $\times$ treatment were incorporated in the model used for summer 2001. Pen within each side was included in the model as a random effect. Data of each trial were analyzed independently. Scraping events were analyzed as repeated measures. First-order autoregressive covariate structure was chosen based on Akaike's information criterion. Results were tabulated by treatment of each study and season. The 1500-h scraping was missed on the second day of sampling during summer 2001 and was analyzed as a missing value. The chain that dragged the scraper was immobilized by ice in pen 7 after the 0100-h sampling in winter 2003. The scraper was restarted after the 0700-h sampling and therefore, the data were analyzed as a missing value. Significance was declared at $P \leq 0.05$, and trends assumed at $0.05 \leq P \leq 0.10$.

\section{RESULTS AND DISCUSSION}

\section{N:P Methodology}

Basic Conditions for Applying the N:P Methodology. It was assumed that $\mathrm{P}$ was not lost from manure in the freestall barn, but that some $\mathrm{N}$ was lost by volatilization as manure accumulated on the floor. Estimates of $\mathrm{N}$ loss using the N:P method can be applicable for livestock operations where manure is contained within handling and storage facilities and $\mathrm{P}$ loss by runoff or leaching is avoided. Manure from the corridors, waiting area, and parlor was not collected, and $\mathrm{N}$ loss was assumed to be similarly affected for both treatments.

Forms of $\mathbf{N}$ Volatilized. Ammonia $\mathrm{N}$ is expected to account for the majority of $\mathrm{N}$ volatilized from manure on the freestall barn floor. There is uncertainty about the extent to which denitrification yields other volatile $\mathrm{N}$ products $\left(\mathrm{N}_{2}\right.$ and $\left.\mathrm{N}_{2} \mathrm{O}\right)$ across the landscape (de Vries et al., 2003). Nevertheless, denitrifying microorganisms require an anaerobic environment and a substrate with high nitrate content. These are unlikely conditions in the current trials. The $\mathrm{N}: \mathrm{P}$ methodology is an indirect technique that can be used to estimate gaseous $\mathrm{N}$ loss from manure. The technique does not distinguish among gaseous forms of $\mathrm{N}$ lost; hence, estimates of $\mathrm{N}$ loss using this procedure must be considered as a maximum estimate of $\mathrm{NH}_{3}-\mathrm{N}$ loss.

The N:P methodology provides an alternative to direct air measurements of volatile $\mathrm{N}$ loss within dairy freestall barns. Treatment comparisons using direct air measurements would need complete separation of the facilities and accurate control of airflow to avoid crosscontamination (Smits et al., 1995; Braam et al., 1997b).

Risk of Nutrient Contamination of the Manure. Wasted feed was avoided when front alleys were scraped to minimize potential nutrient contamination of manure. Bedding (wheat straw; 95.3\% DM, 0.5\% N, and $0.054 \% \mathrm{P}$ ) added to the back alleys was expected to have little effect on $\mathrm{N}: \mathrm{P}_{\operatorname{man}}$. Given the concentration of $\mathrm{N}$ and $\mathrm{P}$ in the excreta in each pen, and assuming $65 \%$ of diet DM digestibility (to account for the amount of excreta), it was estimated that contamination of manure by chopped wheat straw may cause an underestimate of $\mathrm{N}$ loss of less than 1 percentage unit, or $5.3 \mathrm{~g} /$ d per cow.

\section{Diet Composition and Animal Status}

The TMR fed during each of the 3 trials were similar to the diets offered to the whole lactating herd at the time of the study (Table 1). Dietary CP and P contents in all 3 trials were intentionally kept at or above the NRC (2001) minimum recommendation for milk production and composition achieved by the cows before 
Table 2. Chemical composition of experimental diets fed during summer (2001 and 2002) and winter (2003) trials evaluating the effect of manure scraping frequency on $\mathrm{N}$ volatilization from a freestall barn

\begin{tabular}{|c|c|c|c|c|}
\hline & \multicolumn{2}{|c|}{ Summer 2001} & \multirow{2}{*}{$\begin{array}{l}\text { Summer } \\
2002\end{array}$} & \multirow{2}{*}{$\begin{array}{l}\text { Winte } \\
2003\end{array}$} \\
\hline & $\operatorname{Diet} A^{1}$ & Diet $B^{2}$ & & \\
\hline $\mathrm{DM}, \%$ & 51.5 & 49.3 & 61.1 & 59.1 \\
\hline $\mathrm{CP}, \%$ of $\mathrm{DM}$ & 19.2 & 19.2 & 18.5 & 19.3 \\
\hline RUP, ${ }^{3} \%$ of DM & 7.03 & 7.03 & 6.40 & 6.50 \\
\hline $\mathrm{NDF},{ }^{4} \%$ of DM & 28.5 & 28.4 & 28.0 & 27.1 \\
\hline $\mathrm{N}, \%$ of $\mathrm{DM}$ & 3.08 & 3.08 & 2.96 & 3.09 \\
\hline $\mathrm{P}, \%$ of $\mathrm{DM}$ & 0.38 & 0.55 & 0.37 & 0.44 \\
\hline
\end{tabular}

${ }^{1}$ Diet A contained phosphorus to meet requirement $(0.38 \% \mathrm{P})$.

${ }^{2}$ Diet B contained phosphorus to exceed requirement $(0.55 \% \mathrm{P})$.

${ }^{3}$ RUP estimated with NRC (2001) model.

${ }^{4} \mathrm{NDF}$ as estimated with NRC (2001) model.

and during the experimental periods (Table 2). Table 3 contains estimates of DMI, measured milk yield, and milk $\mathrm{N}$ content, and estimated $\mathrm{N}$ and $\mathrm{P}$ excretion. Although actual measurements of DMI would be preferred, estimates of DMI using the NRC model are likely to be reasonably accurate (Hristov et al., 2004). A precise estimate of DMI is not essential for an acceptable estimate of $\mathrm{N}: \mathrm{P}_{\text {exc }}$. For instance, a $10 \%$ error in estimating DMI results in $<2 \%$ error in the calculated $\mathrm{N}: \mathrm{P}_{\text {exc }}$. However, accurate measurements of dietary $\mathrm{N}$ and $\mathrm{P}$ contents and milk $\mathrm{N}$ and $\mathrm{P}$ outputs are essential for obtaining an accurate $\mathrm{N}: \mathrm{P}_{\text {exc }}$ value.

Average milk yield in each pen ranged from 27.7 to $36.6 \mathrm{~kg} / \mathrm{d}$ during the 3 trials. Greater milk production was achieved during winter 2003 , probably because the cows were earlier in lactation and were not affected by the heat-stressing conditions of the summer trials. The summer 2001 trial was carried out concurrently with a long-term $\mathrm{P}$ feeding experiment and its results were published elsewhere (Lopez et al., 2004a,b). Feeding dietary P above the NRC (2001) recommendation did not influence any of the animal performance traits evaluated. Feeding $\mathrm{P}$ in excess of the cows' requirement increases $\mathrm{P}$ content of the feces (Wu et al., 2000). Any possible effect of dietary $\mathrm{P}$ on estimates of $\mathrm{N}$ loss from excreta was balanced by applying each treatment (scraping frequency) to each of 2 pens containing diet $\mathrm{A}$ and diet B (Figure 1 and Table 2).

Estimates of $\mathrm{N}$ loss from manure based on the $\mathrm{N}: \mathrm{P}$ ratio technique did not account for nutrient changes in the body over the lactation period. Nitrogen and $\mathrm{P}$ retention during lactation was estimated at $1 \%$ of the ingested nutrient, assuming $16.5 \% \mathrm{CP}$ and $0.40 \% \mathrm{P}$ in the diet DM. This included $\mathrm{N}$ and $\mathrm{P}$ retained as growth of first-lactation (75\% of mature BW) and second-lactation (85\% of mature BW) cows, and retention in the form of conceptus in a herd with a 13-mo calving interval and culling rate of $33 \%$. As with DMI, changes in body N and $\mathrm{P}$ are expected to have little impact on calculated $\mathrm{N}: \mathrm{P}_{\text {exc. }}$. Therefore, changes in body nutrient ( $\mathrm{N}$ and $\mathrm{P}$ ) over the experimental periods were assumed to be zero.

\section{Summer 2001 Trial}

Air Temperature and Manure Analyses. Urinary urea on a feces-fouled freestall floor can be quickly hydrolyzed to $\mathrm{NH}_{3}$ with summer temperatures. Free $\mathrm{NH}_{3}$ is prone to volatilization depending on air temperature and exchange, manure $\mathrm{pH}$, and the partial pressure of $\mathrm{NH}_{3}$ at the boundary between manure and the surrounding air (Monteny and Erisman, 1998). Average air temperature outside the barn throughout the sampling period was $18.5 \pm 4.8^{\circ} \mathrm{C}$; maximum $=27^{\circ} \mathrm{C}$; minimum $=11^{\circ} \mathrm{C}$ ).

Table 3. Actual milk yield and estimated nutrient intake and excretion by cows during each trial (summer 2001, summer 2002, winter 2003; means \pm SD) evaluating the effect of manure scraping frequency on $\mathrm{N}$ volatilization from a freestall barn

\begin{tabular}{|c|c|c|c|c|}
\hline & \multicolumn{2}{|c|}{ Summer 2001} & \multirow[b]{2}{*}{ Summer 2002} & \multirow[b]{2}{*}{ Winter 2003} \\
\hline & $\operatorname{Diet} \mathrm{A}^{1}$ & Diet $B^{2}$ & & \\
\hline $\mathrm{DMI},{ }^{3} \mathrm{~kg} / \mathrm{d}$ & $23.8 \pm 2.60$ & $24.2 \pm 2.37$ & $22.6 \pm 2.26$ & $25.9 \pm 3.26$ \\
\hline $\mathrm{N}$ intake, ${ }^{3} \mathrm{~kg} / \mathrm{d}$ & $0.735 \pm 0.080$ & $0.744 \pm 0.073$ & $0.668 \pm 0.067$ & $0.799 \pm 0.102$ \\
\hline $\mathrm{P}$ intake, ${ }^{3} \mathrm{~kg} / \mathrm{d}$ & $0.091 \pm 0.010$ & $0.133 \pm 0.013$ & $0.083 \pm 0.008$ & $0.114 \pm 0.014$ \\
\hline Milk yield, $\mathrm{kg} / \mathrm{d}$ & $31.2 \pm 6.99$ & $32.1 \pm 6.37$ & $27.7 \pm 6.08$ & $36.6 \pm 8.86$ \\
\hline Milk N, kg/d & $0.156 \pm 0.035$ & $0.161 \pm 0.032$ & $0.139 \pm 0.031$ & $0.184 \pm 0.044$ \\
\hline Milk P, kg/d & $0.028 \pm 0.006$ & $0.029 \pm 0.006$ & $0.025 \pm 0.005$ & $0.033 \pm 0.008$ \\
\hline Excreted $\mathrm{N},{ }^{4} \mathrm{~kg} / \mathrm{d}$ & $0.578 \pm 0.045$ & $0.584 \pm 0.041$ & $0.529 \pm 0.036$ & $0.615 \pm 0.057$ \\
\hline Excreted $\mathrm{P},{ }^{4} \mathrm{~kg} / \mathrm{d}$ & $0.063 \pm 0.004$ & $0.104 \pm 0.007$ & $0.059 \pm 0.003$ & $0.081 \pm 0.007$ \\
\hline Excreted N:P & $9.24 \pm 0.191$ & $5.61 \pm 0.001$ & $9.02 \pm 0.181$ & $7.61 \pm 0.098$ \\
\hline
\end{tabular}

${ }^{1}$ Diet A contained phosphorus to meet requirement $(0.38 \% \mathrm{P})$.

${ }^{2}$ Diet $\mathrm{B}$ contained phosphorus to exceed requirement $(0.55 \% \mathrm{P})$.

${ }^{3}$ Nutrient intake estimates based on NRC (2001) model.

${ }^{4}$ Nutrient intake minus nutrient in milk. 
Table 4. Manure analyses and estimated $N$ volatilization from manure scraped $2 \times$ or $6 \times$ daily from the alleys of a freestall barn during summer 2001

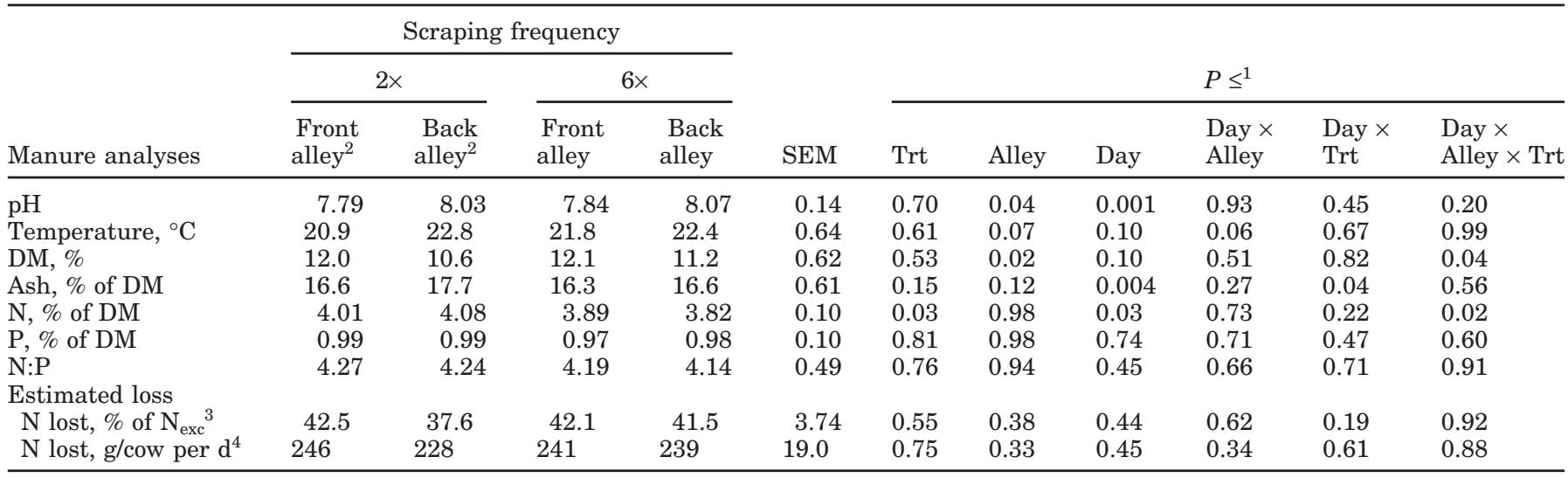

${ }^{1}$ Trt = main effect of treatment; alley = main effect of alley; day = main effect of day; and day $\times$ alley, day $\times$ Trt, $\mathrm{d} \times$ alley $\times$ Trt $=$ interactions.

${ }^{2}$ Manure analyses and estimated loss were based on samples analyzed separately by alley in the freestall barn. The front alley was next to the feed bunk, and the back alley provided access to the freestalls.

${ }^{3}\left[1-\left(\mathrm{N}: \mathrm{P}_{\operatorname{man}} / \mathrm{N}: \mathrm{P}_{\text {exc }}\right)\right] \times 100$, where man $=$ manure and exc $=$ excreta

${ }^{4}\left[1-\left(\mathrm{N}: \mathrm{P}_{\operatorname{man}} / \mathrm{N}: \mathrm{P}_{\text {exc }}\right)\right] \times \mathrm{N}_{\mathrm{exc}}$, where $\mathrm{man}=$ manure and exc $=$ excreta.

It has been suggested that urease activity is limited at manure temperatures below $10^{\circ} \mathrm{C}$ (Muck, 1982). Air temperature is frequently used in place of manure temperature, although ground temperature, which changes more gradually, may have greater influence. Manure temperature measured in the pile after each scraping indicated that urease activity was not limiting. Higher manure $\mathrm{pH}(P \leq 0.04)$ and temperature $(P \leq 0.07)$, and lower DM $(P \leq 0.02)$ were measured in the back alleys for both treatments (Table 4). Urea decomposition increases manure $\mathrm{pH}$ within the first few hours after urination on the barn floor (Muck and Steenhuis, 1981). It was observed that cows deposited less excreta, particularly less urine, in the front alleys than in the back alleys.

Nitrogen content was higher in manure scraped twice daily (Table 4). Phosphorus content of excreta reached nearly 1\% (DM basis) for both treatments (Table 4). Slight changes in the pattern of urination/defecation in the front vs. the back alley may partly explain the significant 3 -way interaction (day $\times$ alley $\times$ treatment) observed for $\mathrm{DM}$ and $\mathrm{N}$, and day and day $\times$ alley effects on manure $\mathrm{pH}$, temperature, $\mathrm{DM}$, ash, and $\mathrm{N}$ content. For instance, cows in pen 7 were locked for an unusually long period in the front alley to allow for the passage of cows returning to pen 5 from the parlor during the second 24-h period. Different patterns of excretion have been reported in the literature. Muck and Richards (1983) observed more urine deposited close to the feed bunk than near the stalls. A possible explanation for this difference may be that cows in our study had access to stalls only from the back alley, whereas cows had access to a row of stalls from the alley closer to the feed bunk in the study described by Muck and Richards (1983).

Effect of Scraping Frequency on N:P and N Volatilization Estimates. Scraping frequency did not affect $\mathrm{N}: \mathrm{P}_{\operatorname{man}}$ nor $\mathrm{N}$ loss (\% of $\mathrm{N}_{\mathrm{exc}}$ or g/d per cow). Nevertheless, a large proportion of $\mathrm{N}$ excreted in manure was apparently volatilized (37.5 to $43.1 \%$ or 228 to $246 \mathrm{~g} / \mathrm{d}$ per cow; Table 4). The fact that volatile $\mathrm{N}$ loss was similar between front and back alleys coupled with the observation that very little urine was deposited in the front alleys may suggest that most urinary $\mathrm{N}$ was lost by the time samples were taken from the barn floor.

\section{Summer 2002 Trial}

Air Temperature and Manure Analyses. Air temperatures measured at approximately $2.5 \mathrm{~m}$ above the floor inside the freestall barn averaged $21.8 \pm 3.27^{\circ} \mathrm{C}$; maximum $=27.5^{\circ} \mathrm{C}$; minimum $=15.3^{\circ} \mathrm{C}$ ). Day $\times$ treatment interaction was significant for most traits evaluated, except manure temperature and $\mathrm{N}$ content (Table $5)$. That interaction could have been a result of higher air temperatures $\left(2.5^{\circ} \mathrm{C}\right)$ on the second day of sampling or an effect of side of the barn (north or south) affecting manure analyses differently. It was noteworthy that the treatment response patterns remained similar for $\mathrm{DM}$, ash, $\mathrm{P}$, and $\mathrm{N}: \mathrm{P}$ of the manure between north and south pens (data not shown). The higher concentration of ash $(P \leq 0.02)$ and $\mathrm{P}(P \leq 0.001)$ in manure scraped twice daily suggests that as much as 6 to $7 \%$ more manure DM may have decomposed when urine and 
Table 5. Manure analyses and estimated $N$ volatilization from manure scraped $2 \times$ or $6 \times$ daily from the alleys of a freestall barn during summer 2002

\begin{tabular}{|c|c|c|c|c|c|c|}
\hline \multirow[b]{2}{*}{ Manure analyses } & \multicolumn{2}{|c|}{ Scraping frequency } & \multirow[b]{2}{*}{ SEM } & \multicolumn{3}{|c|}{$P \leq 1$} \\
\hline & $2 \times$ & $6 x$ & & Trt & Day & Day $\times$ Trt \\
\hline $\mathrm{pH}$ & 8.62 & 8.57 & 0.04 & 0.30 & 0.003 & 0.01 \\
\hline Temperature, ${ }^{\circ} \mathrm{C}$ & 22.9 & 23.5 & 0.47 & 0.18 & 0.87 & 0.44 \\
\hline $\mathrm{DM}, \%$ & 10.8 & 11.1 & 0.33 & 0.33 & 0.63 & 0.04 \\
\hline Ash, \% of DM & 18.3 & 17.5 & 0.30 & 0.02 & 0.11 & $<0.001$ \\
\hline $\mathrm{N}, \%$ of $\mathrm{DM}$ & 3.86 & 3.85 & 0.09 & 0.87 & 0.62 & 0.46 \\
\hline $\mathrm{P}, \%$ of $\mathrm{DM}$ & 0.87 & 0.80 & 0.02 & 0.001 & 0.18 & $<0.001$ \\
\hline $\mathrm{N}: \mathrm{P}$ & 4.51 & 4.80 & 0.08 & 0.001 & 0.99 & $<0.001$ \\
\hline \multicolumn{7}{|l|}{ Estimated loss } \\
\hline $\mathrm{N}$ lost, $\%$ of $\mathrm{N}_{\mathrm{exc}}^{2}$ & 50.0 & 46.7 & 0.94 & 0.002 & 0.96 & $<0.001$ \\
\hline $\mathrm{N}$ lost, g/cow per d ${ }^{3}$ & 265 & 248 & 5.00 & 0.002 & 0.97 & $<0.001$ \\
\hline
\end{tabular}

${ }^{1}$ Trt = main effect of treatment; day = main effect of day; and day $\times$ Trt = interaction between day and treatment.

${ }^{2}\left[1-\left(\mathrm{N}: \mathrm{P}_{\operatorname{man}} / \mathrm{N}: \mathrm{P}_{\mathrm{exc}}\right)\right] \times 100$, where man = manure and exc $=$ excreta.

${ }^{3}\left[1-\left(\mathrm{N}: \mathrm{P}_{\operatorname{man}} / \mathrm{N}: \mathrm{P}_{\mathrm{exc}}\right)\right] \times \mathrm{N}_{\mathrm{exc}}$, where man $=$ manure and exc $=$ excreta.

feces remained on the concrete floor for longer periods of time with the $2 \times$ treatment. The previous experiment exhibited a similar trend, but the differences were not as large.

The rate of $\mathrm{NH}_{3}$ volatilization is a product of the $\mathrm{NH}_{3}$ mass transfer coefficient and the difference in concentration or partial pressure of gaseous $\mathrm{NH}_{3}$ between the manure boundary and the air above (Monteny and Erisman, 1998). Partial pressure depends on $\mathrm{NH}_{3}$ concentration, temperature, and air exchange at the manureair boundary. High air and manure temperatures (above $20^{\circ} \mathrm{C}$ ) throughout the experimental period were conducive to $\mathrm{NH}_{3}$ volatilization and microbial decomposition of manure organic matter.

Effect of Scraping Frequency on N:P and N Volatilization Estimates. Day $\times$ treatment interaction was significant for all traits evaluating $\mathrm{N}$ volatilization. The differences between $2 \times$ and $6 \times$ remained similar for $\mathrm{N}: \mathrm{P}$ $(0.30 \pm 0.001)$ and $\mathrm{N}$ loss $(3.7 \pm 0.06$ percentage units $)$ in north pens and south pens. Scraping less frequently resulted in higher $\mathrm{N}$ loss $(P \leq 0.002$; Table 5) from manure on the barn floor, although the difference in $\mathrm{N}$ loss between $2 \times$ and $6 \times$ was small. The magnitude of reduction in volatile $\mathrm{N}$ loss attained by scraping $6 \times$ vs. $2 \times$ was only 3.3 percentage units, or $17 \mathrm{~g}$ of $\mathrm{N} / \mathrm{d}$ per cow (a $6.4 \%$ reduction). The small difference in $\mathrm{N}$ loss observed between $2 \times$ and $6 \times$ scraping in this experiment, plus the absence of a difference in the previous experiment, suggests that the decrease in $\mathrm{N}$ volatilization with increased scraping frequency is small and may not be enough to offset the consequent increase in equipment and energy costs associated with frequent scraping.

\section{Winter 2003 Trial}

Air Temperature and Manure Analyses. Air temperatures measured at a height of $2.5 \mathrm{~m}$ inside the freestall barn averaged $-3.78 \pm 2.58^{\circ} \mathrm{C}$; maximum $=$ $3.50^{\circ} \mathrm{C}$; minimum $=-7.50^{\circ} \mathrm{C}$ ). Manure $\mathrm{pH}$ was higher with the $2 \times$ than with the $6 \times$ treatment $(P \leq 0.002$; Table 6). Manure $\mathrm{P}(0.74 \pm 0.01$ vs. $0.68 \pm 0.01)$ and $\mathrm{pH}$ $(8.16 \pm 0.03$ vs. $8.05 \pm 0.03)$ were higher during the second day of sampling. Very low air and manure temperatures observed during this experiment probably limited microbial and urease activity (Muck and Steenhuis, 1981; Muck, 1982).

Effect of Scraping Frequency on N:P and N Volatilization Estimates. Nitrogen disappearance from manure on the barn floor was similar for both treatments during the winter 2003 trial (Table 6). Loss of $\mathrm{N}$ tended to be higher during the second day of the collection period $(120.9 \pm 9.1$ vs. $97.2 \pm 9.1 \mathrm{~g})$. Air temperatures below freezing for most of the day and low manure temperature probably limited urease activity (thus reducing $\mathrm{NH}_{3}$ available for volatilization), water evaporation, and $\mathrm{NH}_{3}$ emission (Muck, 1982).

\section{Estimation of $\mathbf{N}$ Loss from Manure in the Freestall Barn}

Effect of Scraping Frequency. Frequent scraping of manure from the barn floor did not result in lower $\mathrm{N}$ volatilization because of the shorter exposure time of manure, supporting Braam et al. (1997a) who found that scraping manure 96 vs. 12 times/d resulted in only a 5\% decrease in $\mathrm{NH}_{3}$ volatilization. It may be that a relatively large proportion of volatilized $\mathrm{N}$ is actually lost within 3 to $5 \mathrm{~h}$ of excretion. More likely, frequent scraping may enhance volatile $\mathrm{N}$ loss under certain circumstances because scraping may increase the surface area onto which urine is spread and decrease thickness of the urine pool, thus increasing $\mathrm{N}$ volatilization (Braam et al., 1997b). Frequent scraping of freestall barns does not seem to significantly reduce $\mathrm{N}$ volatiliza- 
Table 6. Manure analyses and estimated $N$ volatilization from manure scraped $2 \times$ or $6 \times$ daily from the alleys of a freestall barn during winter 2003

\begin{tabular}{|c|c|c|c|c|c|c|}
\hline \multirow[b]{2}{*}{ Manure analyses } & \multicolumn{2}{|c|}{ Scraping frequency } & \multirow[b]{2}{*}{ SEM } & \multicolumn{3}{|c|}{$P \leq^{1}$} \\
\hline & $2 \times$ & $6 \times$ & & Trt & Day & Day $\times$ Trt \\
\hline $\mathrm{pH}$ & 8.18 & 8.02 & 0.04 & 0.002 & 0.02 & 0.36 \\
\hline Temperature, ${ }^{\circ} \mathrm{C}$ & 1.07 & 1.53 & 0.65 & 0.54 & 0.22 & 0.52 \\
\hline $\mathrm{DM}, \%$ & 12.1 & 12.3 & 0.32 & 0.49 & 0.16 & 0.46 \\
\hline Ash, \% of DM & 16.4 & 16.7 & 0.46 & 0.58 & 0.09 & 0.14 \\
\hline $\mathrm{N}, \%$ of $\mathrm{DM}$ & 4.47 & 4.34 & 0.08 & 0.20 & 0.09 & 0.40 \\
\hline $\mathrm{P}, \%$ of $\mathrm{DM}$ & 0.71 & 0.71 & 0.02 & 0.96 & 0.004 & 0.08 \\
\hline $\mathrm{N}: \mathrm{P}$ & 6.39 & 6.13 & 0.13 & 0.11 & 0.06 & 0.20 \\
\hline \multicolumn{7}{|l|}{ Estimated loss } \\
\hline $\mathrm{N}$ lost, $\%$ of $\mathrm{N}_{\mathrm{exc}}^{2}$ & 16.0 & 19.4 & 1.77 & 0.11 & 0.06 & 0.15 \\
\hline $\mathrm{N}$ lost, g/cow per $\mathrm{d}^{3}$ & 99.0 & 119.0 & 11.0 & 0.11 & 0.06 & 0.11 \\
\hline
\end{tabular}

${ }^{1}$ Trt = main effect of treatment; day = main effect of day; and day $\times$ Trt $=$ interaction between day and treatment.

${ }^{2}\left[1-\left(\mathrm{N}: \mathrm{P}_{\operatorname{man}} / \mathrm{N}: \mathrm{P}_{\text {exc }}\right)\right] \times 100$, where man $=$ manure and exc $=$ excreta.

${ }^{3}\left[1-\left(\mathrm{N}: \mathrm{P}_{\operatorname{man}} / \mathrm{N}: \mathrm{P}_{\mathrm{exc}}\right)\right] \times \mathrm{N}_{\mathrm{exc}}$, where man $=$ manure and exc $=$ excreta.

tion. Based on current results and data from other studies (Muck, 1982; Braam et al., 1997a,b; Monteny and Erisman, 1998), a better alternative may be to design barns that allow for rapid urine removal to minimize urea hydrolysis.

Effect of Season. Statistical comparison among seasons was not possible in our study because different diets were offered during each experiment (Table 1). However, losses estimated during the summer 2001 and summer 2002 trials were similar. The coefficient of variation across treatments and alleys was approximately $5 \%$. Nitrogen losses in the summer trials were more than twice those noted in the winter trial. Todd et al. (2005) made similar estimations of $\mathrm{NH}_{3}$ volatilization from beef feedlots between summer and winter. Temperature was indicated as one of the most important factors affecting urease activity and $\mathrm{NH}_{3}$ volatilization, and probably explains these results (Muck, 1982; Monteny and Erisman, 1998).

Annual N Loss from Freestall Barn. Nitrogen losses were greater in the present study than has usually been reported (Smits et al., 1995; Kröber et al., 2000; USEPA, 2004). Extrapolating N volatilization figures from summer to represent the warmer half of the year and those from winter to represent the cooler half of the year, about $60 \mathrm{~kg}$ of $\mathrm{N}$ would be lost annually from the manure in the freestall barn from each lactating dairy cow. It is important to note that this does not include $\mathrm{N}$ loss during manure storage and field application.

The draft report of the National Emission Inventory (EPA, 2004) suggested overall $\mathrm{NH}_{3}$ emissions of $31 \mathrm{~kg}$ of $\mathrm{NH}_{3}-\mathrm{N} / \mathrm{yr}$ per cow over the entire dairy production system. Although $\mathrm{NH}_{3}-\mathrm{N}$ loss may be less than total $\mathrm{N}$ loss measured in our study, it is not likely to be much less. Relatively higher dietary $\mathrm{N}$ was used in our study, which would result in somewhat higher $\mathrm{N}$ loss. Nitrogen excretion by the average lactating dairy cow in the EPA inventory was $0.45 \mathrm{~kg} / \mathrm{d}$ per cow, approximately $28 \%$ lower than the average estimated excretion in our study. Smits et al. (1995) observed that N loss increased $63 \%$ when cows were fed a diet containing $20 \% \mathrm{CP}$ compared with cows fed a $14.7 \% \mathrm{CP}$ diet. Kröber et al. (2000) detected a 56\% increase in N loss when comparing a $17.5 \% \mathrm{CP}$ diet to a $14.7 \% \mathrm{CP}$ diet. Nonetheless, both groups found losses lower than those presented in the current trials. The former estimated that less than $50 \mathrm{~g}$ of N/d per cow was lost as measured directly from the barn by first converting atmospheric $\mathrm{NH}_{3}$ to $\mathrm{NO}$ with a high-temperature catalyst. Kröber et al. (2000) used the same technique to determine that $88.6 \mathrm{~g}$ of N/ $\mathrm{d}$ per cow were lost. However, in that study, urine and feces were thawed, mixed, and then placed into forcedair dynamic chambers for $7 \mathrm{wk}$ for measurement; these conditions do not necessarily simulate barn conditions.

Filipy et al. (2004) recently reported total annual $\mathrm{NH}_{3}-\mathrm{N}$ emissions of $140 \pm 41 \mathrm{~kg} / \mathrm{yr}$ per cow over the entire Washington State University dairy operation. Measurements were taken using the sulfur hexafluoride $\left(\mathrm{SF}_{6}\right)$ tracer technique. Their high $\mathrm{N}$ loss agrees with the losses found in the current trials, assuming that manure $\mathrm{N}$ losses reach 30,10 , and $25 \%$ of excreted $\mathrm{N}$ from housing, liquid storage, and land application, respectively. Results suggest that the EPA $\mathrm{NH}_{3}$ volatilization estimates may be low.

\section{CONCLUSIONS}

The results of 3 separate trials conducted during 2 summers and 1 winter indicated that increasing scraping frequency of dairy freestall barn floors from 2 to 6 times daily has little effect on $\mathrm{N}$ volatilization from 
manure. It was estimated that 40 to $50 \%$ (228 to 265 $\mathrm{g} / \mathrm{d}$ per cow) of the $\mathrm{N}$ excreted during the summer and less than $20 \%$ (99 to $119 \mathrm{~g} / \mathrm{d}$ per cow) of the $\mathrm{N}$ excreted during the winter may have been lost from the barn floor when cows were fed diets containing about $19 \%$ CP.

\section{ACKNOWLEDGMENTS}

The authors are grateful to Fern Kanitz, Claudia Leonardi, Matias Aguerre, David Dominguez-Dias, Honorato Santos, Zachary Schott, Kathleen Herbert, Amber Rew, Amy Kuhn, and Mary Becker for helping with manure scraping, sampling, and analyses. This project was partially supported by Initiative for Future Agriculture and Food Systems Grant no. 00-52103-9658 from the USDA Cooperative State Research, Education, and Extension Service.

\section{REFERENCES}

AOAC. 1990. Official Methods of Analysis. 15th ed. Association of Official Analytical Chemists, Arlington, VA.

Braam, C. R., J. J. M. H. Ketelaars, and M. C. J. Smits. 1997a. Effects of floor design and floor cleaning on ammonia emission from cubicle houses for dairy cows. Neth. J. Agric. Sci. 45:49-64.

Braam, C. R., M. C. J. Smits, H. Gunnink, and D. Swierstra. 1997b. Ammonia emission from a double-sloped solid floor in a cubicle house for dairy cows. J. Agric. Eng. Res. 68:375-386.

Bussink, D. W., and O. Oenema. 1998. Ammonia volatilization from dairy farming systems in temperate areas: A review. Nut. Cycl. Agroecosys. 51:19-33.

Carpenter, S. R., N. F. Caraco, D. L. Correll, R. W. Howarth, A. N. Sharpley, and V. H. Smith. 1998. Nonpoint polluting of surface waters with phosphorus and nitrogen. Ecol. Appl. 8:559-568.

Combs, D. K., and L. D. Satter. 1992. Determination of markers in digesta and feces by direct current plasma emission spectroscopy. J. Dairy Sci. 75:2176-2183.

de Vries, W., J. Kros, O. Oenema, and J. de Klein. 2003. Uncertainties and fate of N II: A quantitative assessment of the uncertainties in major nitrogen fluxes in the Netherlands. Nut. Cycl. Agroecosys. 66:71-102.

ECETOC. 1994. Ammonia Emissions to Air in Western Europe. Technical Report No. 62. European Centre for Ecotoxicology and Toxicology of Chemicals (ECETOC), Brussels, Belgium.

Environmental Protection Agency (EPA). 2004. National Emission Inventory. Ammonia Emissions from Animal Husbandry Operations-Draft Report. United States EPA, Washington, DC.

Filipy, J. M., B. K. Lamb, R. L. Kincaid, and K. A. Johnson. 2004. Emissions of atmospheric ammonia and a nitrogen mass balance for a dairy. J. Dairy Sci. 87(Suppl. 1):301-302. (Abstr.)

Frank, B., and C. Swensson. 2002. Relationship between content of crude protein in rations for dairy cows and milk yield, concentra- tion of urea in milk and ammonia emissions. J. Dairy Sci 85:1829-1838.

Hristov, A. N., M. J. Price, and B. Shafii. 2004. A meta-analysis examining the relationship among dietary factors, dry matter intake, and milk and milk protein yield in dairy cows. J. Dairy Sci. 87:2184-2196.

Kaiser, J. 2005. Mounting evidence indicts fine-particle pollution. Science 307:1858-1861.

Kröber, T. F., D. R. Kulling, H. Menzi, F. Sutter, and M. Kreuzer. 2000. Quantitative effects of feed protein reduction and methionine on nitrogen use by cows and nitrogen emission from slurry. J. Dairy Sci. 83:2941-2951.

Lopez, H., F. D. Kanitz, V. R. Moreira, M. C. Wiltbank, and L. D. Satter. 2004a. Effect of dietary phosphorus on performance of lactating dairy cows: Milk production and cow health. J. Dairy Sci. 87:139-146.

Lopez, H., F. D. Kanitz, V. R. Moreira, L. D. Satter, and M. C. Wiltbank. 2004b. Reproductive performance of dairy cows fed two concentrations of phosphorus. J. Dairy Sci. 87:146-157.

Monteny, G. J., and J. W. Erisman. 1998. Ammonia emission from dairy cow buildings: A review of measurement techniques, influencing factors and possibilities for reduction. Neth. J. Agric. Sci. 46:227-247.

Muck, R. E. 1982. Urease activity in bovine feces. J. Dairy Sci. 65:2157-2163.

Muck, R. E., and B. K. Richards. 1983. Losses of manurial nitrogen in free-stall barns. Agric. Waste 7:65-79.

Muck, R. E., and T. S. Steenhuis. 1981. Nitrogen losses in free-stall dairy barns. Pages 406-409 in Livestock Waste: A Renewable Resource. Am. Soc. Agric. Eng., St. Joseph, MI.

NRC. 2001. Nutrient Requirements of Dairy Cattle. 7th rev. ed. Natl. Acad. Sci., Washington, DC.

NRC. 2003. Air emissions from animal feeding operations: Current knowledge, future needs. Natl. Acad. Sci., Washington, DC

Rabalais, N. N. 2002. Nitrogen in aquatic ecosystems. Ambio 31:102-112.

SAS Institute. 1999. SAS Online Doc. Version 8.0. SAS Institute, Inc., Cary, NC.

Smits, M. C. J., H. Valk, A. Elzing, and A. Keen. 1995. Effect of protein nutrition on ammonia emission from a cubicle house for dairy cattle. Livest. Prod. Sci. 44:147-156.

Tilman, D. 1999. Global environmental impacts of agriculture expansion: The need for sustainable and efficient practices. Proc. Natl. Acad. Sci. USA 96:5995-6000.

Todd, R. W., N. A. Cole, L. A. Harper, T. K. Flesch, and B. H. Back. 2005. Ammonia and gaseous nitrogen emissions from a commercial beef cattle feedyard estimated using the flux-gradient method and N:P ratio analysis. In Proc. Symp. State of the Art: Animal manure and waste management, Natl. Center for Manure and Animal Waste Management, CSREES, San Antonio, TX. Online: http://www.cals.ncsu.edu/waste_mgt/natlcenter/center.htm

Van Horn, H. H., A. C. Wilkie, W. J. Powers, and R. A. Nordstedt. 1994. Components of dairy manure management systems. J. Dairy Sci. 77:2008-2030.

Wolfe, A. H., and J. A. Patz. 2002. Reactive nitrogen and human health: Acute and long-term implications. Ambio 31:120-125.

Wu, Z., L. D. Satter, and R. Sojo. 2000. Milk production, reproductive performance, and fecal excretion of phosphorus by dairy cows fed three amounts of phosphorus. J. Dairy Sci. 83:1028-1041. 